CENTRE POUR LA RECHERCHE ECONOMIQUE ET SES APPLICATIONS

Document de travail (Docweb) no 1517

\title{
Self-Reported Health and Gender: the Role of Social Norms
}

Eve Caroli

Lexane Weber-Baghdiguian 


\title{
Self-Reported Health and Gender: the Role of Social Norms ${ }^{1}$
}

Eve Caroli $^{2}$ and Lexane Weber-Baghdiguian ${ }^{3}$

\begin{abstract}
We investigate the role of social norms in accounting for differences in self-reported health as reported by men and women. Using the European Working Conditions Survey (EWCS, 2010), we first replicate the standard result that women report worse health than men, whatever the health outcome we consider - i.e. general self-assessed health, well-being but also more specific symptoms such as hearing problems, skin problems, backache, muscular pain in upper or lower limbs, headache and eyestrain, stomach ache, respiratory difficulties, depression and anxiety, fatigue and insomnia. We then proxy social norms by the gender structure of the workplace environment and study how the latter affects self-reported health for men and women separately. Our findings indicate that individuals in workplaces where women are a majority tend to report worse health than individuals employed in mixed-gender work environments, be they men or women. The opposite holds for individuals in workplaces where men are a majority: men tend to report fewer health problems than when employed in mixed-gender environments and the same goes for women - although the effects are not significant at conventional levels. These results are robust to controlling for a large array of working condition indicators, which allows us to rule out that the poorer health status reported by individuals working in female-dominated environments could be due to worse job quality. We interpret this evidence as suggesting that social norms associated with specific gender environments play an important role in explaining differences in health-reporting behaviours across sex, at least in the workplace.
\end{abstract}

Keywords: health, gender, social norms, job quality

JEL Classification: I12, I19, J16

1 We are grateful to Andrea Bassanini, Clémentine Garrouste, Mathilde Godard, Mathilde Peron, Anne-Laure Samson, Loup Wolff and participants to the TEPP Public Policy Evaluation Winter School and DEFAP/LASER summer school in Applied Microeconometrics and LEDa-LEGOS and EuHEA seminars for useful comments and suggestions. All remaining errors are our own. The authors acknowledge financial support of Health Chair $-\mathrm{a}$ joint initiative by PSL, Université Paris-Dauphine, ENSAE, MGEN and ISTYA under the aegis of the Fondation du Risque (FDR). EWCS data were kindly provided by the European Foundation for the Improvement of Living and Working Conditions.

2 PSL, University Paris Dauphine, LEDa-LEGOS, Paris School of Economics and IZA. Corresponding author Address: Université Paris Dauphine, LEDa-LEGOS, Place du Maréchal de Lattre de Tassigny, 75775 Paris Cedex 16. Tel: 33144054302 / 331431363 25. Email: eve.caroli@dauphine.fr

3 PSL, University Paris Dauphine, LEDa-LEGOS. 


\section{La santé auto-déclarée des hommes et des femmes : le rôle des normes sociales}

Eve Caroli et Lexane Weber-Baghdiguian

Résumé : Nous étudions l'impact des normes sociales sur les différences de santé auto-déclarée entre les hommes et les femmes. Nous utilisons, pour ce faire, l'Enquête Européenne sur les Conditions de Travail (EWCS, 2010). Dans un premier temps, nous répliquons le résultat classique selon lequel les femmes déclarent une plus mauvaise santé que les hommes quel que soit l'indicateur de santé considéré - santé générale auto-déclarée, bien-être, mais aussi différents symptômes plus spécifiques tels que les problèmes d'audition, les problèmes de peau, le mal de dos, les douleurs musculaires dans les membres inférieurs ou supérieurs, les maux de têtes et la fatigue oculaire, les maux d'estomac, les difficultés respiratoires, la dépression et l'anxiété, la fatigue et l'insomnie. Dans un second temps, nous construisons une mesure approchée de la norme sociale celle-ci est mesurée par la structure par sexe dans l'environnement de travail - et nous étudions son impact sur la santé déclarée des hommes et des femmes. Nous montrons que les individus travaillant dans des environnements où les femmes sont majoritaires déclarent être en plus mauvaise santé que les individus travaillant dans un environnement mixte et ce, qu'ils soient eux-mêmes hommes ou femmes. L'inverse prévaut pour les individus travaillant dans des environnements essentiellement masculins : les hommes déclarent moins de problèmes de santé que les hommes travaillant dans des environnements de genre mixte. Il en va de même pour les femmes, même si les différences ne sont pas significatives aux seuils statistiques conventionnels. Ces résultats sont robustes au fait de contrôler pour un grand nombre d'indicateurs de conditions de travail, ce qui nous permet d'écarter l'hypothèse selon laquelle les individus travaillant dans des environnements essentiellement féminins seraient en plus mauvaise santé car ils occuperaient des emplois de plus mauvaise qualité. Nous interprétons ces résultats comme indiquant que les normes sociales associées à des environnements de travail essentiellement masculins ou féminins jouent un rôle important pour expliquer les écarts de santé déclarée entre les sexes, tout au moins dans l'environnement de travail.

Mots-clefs : santé, genre, normes sociales, qualité du travail

Classification JEL : I12, I19, J16 


\section{Introduction}

The literature on health and gender has long evidenced a striking paradox: women consistently report worse self-rated health than men while their probability of dying is lower than men's throughout their life - Lahelma et al. (1999).

A first explanation of this paradox relies on "true" health differences: women would suffer more than men from chronic diseases generating serious limitations in their activity. Case and Paxson (2005) indeed show that gender differences in self-rated health can be entirely explained by the distribution of chronic conditions. However, the authors also find that men with some specific health conditions are more likely to be hospitalised and die. The reason they consider most plausible to account for this specific pattern is that the symptoms that individuals experience convey little information about the severity of their disease.

Another - potentially complementary - explanation for the gender gap in self-reported health has to do with sex differences in health-reporting behaviour: for given health conditions, women would report worse health status than men do. Health-reporting biases have long been studied in the literature. They have been shown to be potentially large and to vary according to a number of dimensions, including education (Bago d'Uva et al, 2011; Schneider et al, 2012), income (Etilé and Milcent, 2006; Johnston et al, 2009; Schneider et al, 2012), age (Bago d'Uva et al, 2008; Lindeboom and van Doorslaer, 2004) and gender (Bago d'Uva et al, 2008; Lindeboom and van Doorslaer, 2004). Another strand of the literature focuses specifically on the health-reporting behaviour of women as compared to men's and the debate is still open as to whether women tend to over-report minor health problems as compared to men and, if so, why - see the special issues of Social Science \& Medicine, 36(1), 1993 and 48(1), 1999.

A new way to shed light on this issue is to consider whether differences in health-reporting behaviours across genders may be influenced by social norms. The role of social norms has been considered in the health literature mostly in relation with body weight. Christakis and Fowler (2007) provide evidence that weight gains tend to spread though a population via social networks. The extent to which this result can be interpreted as a causal effect of peers' weight on own weight or is, alternatively, due to endogenous peer-group formation has been much discussed since then - see Cohen-Cole and Fletcher (2008), Fowler and Christakis (2008), Halliday and Kwak (2009). Complementary evidence shows that individuals are sensitive to peers' weight: the probability for them to feel overweight or dissatisfied with their weight increases with their relative BMI - computed as the ratio of own BMI to average BMI 
in the reference group, the latter being defined with reference to age, gender and possibly geographic localisation (see Blanchflower et al, 2009). Similarly, life satisfaction appears to decrease with relative BMI. Etilé (2007) goes one step further and shows that social norms play a key role in the determination of ideal body weight, in particular for women. Social norms are captured by the average of ideal $\mathrm{BMI}^{1}$ in the reference group. The results show that the elasticity of women's ideal BMI to the norm is as high as 0.5. In contrast, men do not seem to be sensitive to social norms. Similarly, Gil and Mora (2011) show that women tend to underestimate their weight and that the gap between measured and self-reported weight is affected by social norms: it increases when the ideal weight decreases in the reference group.

Beyond body weight preferences, the literature has not much analysed the potential impact of social norms on other health outcomes. Raspe et al (2007) mention that "social influences" may be one of the explanations for the convergence in prevalence rates of self-reported back pain in Western and Eastern Germany after reunification. The prevalence rate was 10 percentage points higher in Western than in Eastern Germany as of 1991, while the gap had virtually gone down to zero in 2003, because of a sharp increase in reported back pain in the Eastern part of the country over the period. One of the reasons mentioned by the authors to account for this increase is the fact that "back myths and misconceptions about back pain being pervasive in Western societies were immediately disseminated in East Germany". Unfortunately, the authors cannot test this assumption with the data they have. Powdthavee (2009) considers the impact of social norms within the household on potential healthreporting biases. He shows that the specific health problems individuals suffer from have a negative impact on their self-assessed health, but that this impact is significantly lower for individuals living in households where the number of health problems per other family member is high. This result suggests that self-assessed health is potentially biased owing to the "confounding health norm effects", although the bias turns out to be economically very small. One issue raised by Powdthavee has to do with the definition of the reference group. His paper innovates in considering the household as the reference group but he underlines that other people in close proximity, such as friends, colleagues or people in the same region could also be relevant.

In this paper, we investigate the importance of social norms in the working environment in accounting for differences in self-reported health across men and women. Using the European Working Conditions Survey(EWCS, 2010), we first replicate the standard result that women

\footnotetext{
${ }^{1}$ The ideal BMI is computed using the weight individuals report as the one they would like to "reach or keep".
} 
report worse health than men, whatever the health outcome we consider - except hearing problems and cardiovascular diseases. We then proxy social norms by the gender structure of the workplace environment and study how the latter affects self-reported health for men and women separately. Our findings indicate that individuals in workplaces where women are a majority tend to report worse health than individuals employed in mixed-gender work environments, be they men or women. The opposite holds for individuals in workplaces where men are a majority: men tend to report fewer health problems than when employed in mixed-gender environments and the same goes for women - although the effects are not significant at conventional levels. These results are robust to controlling for a large array of working-condition indicators, which allows us to rule out that the poorer health status reported by individuals working in female-dominated environments could be due to worse job quality. We interpret this evidence as suggesting that social norms associated with specific gender environments play an important role in explaining differences in health-reporting behaviours across sex, at least in the workplace.

\section{Health, Gender and Social Norms}

We refer to social norms as defined by Akerlof and Kranton (2000) in terms of "prescriptions", i.e. "shared expectations about how the group members ought ideally to behave". In their model, prescriptions affect identity so that social norms enter in the individual's utility function. A number of authors consider that individuals' utility depends on the dominant social norm within their group - see Brock and Durlauf (2001) and Blanchflower et al. (2009), for example. As a matter of fact, there is evidence that perceptions of social norms influence health behaviours in terms on alcohol consumption, tobacco use, dietary habits etc. - Malahlik et al. (2007). In such a framework we may expect individuals to be more inclined to report poor self-assessed health and/or more health symptoms when belonging to a group in which doing so is more legitimate because it is a commonly-held norm. As underlined by Manski (1993), proper identification of a social-norm effect requires that the group to which individuals are assigned be adequately defined. In what follows, the social group we consider is the group of work colleagues with similar job titles as the individual. We hypothesise that when discussing or even mentioning health problems is considered more legitimate in the reference professional group, individuals will tend to report such problems more easily when asked about their health. 
Our assumption here is that health-reporting norms differ across genders in general, and in the workplace in particular. There is evidence in the literature that women tend to report higher morbidity rates than men, which is in contrast with their longevity advantage. The existence of such a gender-morbidity gap has been highly debated since the 1980s - see Hunt and Annandale (1999). Marshall and Funch (1986) study sex differences in the lag between first recognition of symptoms and definitive diagnosis and treatment for colorectal cancer. Report of pre-diagnostic symptoms and ratings of severity of symptoms did not differ significantly between men and women. Similarly, Macintyre (1993) studies a group of British volunteers who have been inoculated with a cold virus or an inert substance in hospital. The severity of their colds was evaluated both by the respondents themselves and by a clinical observer with double-blind ratings. The results suggest that women were not more likely than men to assess themselves as having a cold. Men were significantly more likely than women to over-rate their cold symptoms as compared to the observer's ratings. Another example is Arber and Cooper (1999) who consider men and women over 60 with similar levels of disability and find that men rather than women are more likely to assess their health as being poor, after accounting for structural factors.

In contrast, a large strand of literature does find greater reported morbidity among women. Hibbard and Pope (1983) use US data covering adults, most of whom are husband and wife pairs. The sample under study is restricted to respondents who rated their health as good or excellent. The authors find that women report more symptoms than men do. Similar results are found by Verbrugge (1989) on the Health in Detroit survey: women show higher morbidity on almost all health indicators with an especially large gap for circulation and nervous conditions over the past twelve months. Popay et al. (1993) also find that women report more affective disorders and minor physical morbidity than men in a survey covering individuals aged 18 and above in England, Wales and Scotland (the Health and Lifestyles Survey). Using the UK Whitehall II survey of London-based Civil Servants, Emslie et al (2002) find that women report greater psychiatric morbidity, especially when employed in higher positions. This is confirmed by Zunzunegui et al. (2009) on data collected in San Paolo, Santiago and Mexico: women showed poorer health outcomes than men for all health indicators in all cities.

This gender gap in health reporting has been found to be partly due to different health attitudes across genders. According to Kessler et al (1981), women are more likely to interpret symptoms associated with depression and low well-being as signs of emotional problems and 
hence to get psychiatric help. This suggests that women perceive symptoms in a different way as compared to men, so that they also seek more medical care. Hibbard and Pope (1983) find that women also report higher interest and concern about health than men do. This is confirmed by Verbrugge (1989) who finds that health matters are more salient among women, that they value health more than men do and that they have more responsibility in caring for ill family members. Such findings are consistent with the idea that women pay more attention to health than men do. Hibbard and Pope (1986) also find evidence that the largest gaps in health symptoms reported by women as compared to men are found for those categories which represent milder morbidities and those where there is a great degree of discretion in defining illness and/or the need for care. This brings the authors to the conclusion that sex differences reflect differences in the way in which men and women come to define themselves as "ill". More recent evidence goes in the same direction. Emslie et al (1999) study gender differences in physical symptoms, malaise symptoms ${ }^{2}$ and GHQ-12 psychiatric morbidity. They find that gender-role orientation - as measured by the BSRI score ${ }^{3}$ - plays an important role: the masculinity score is associated both with fewer reported malaise symptoms and better psychiatric health while the femininity score is associated with more malaise symptoms. All these findings suggest that health matters may be more important to women than to men and that admitting illnesses and discussing symptoms may be socially more acceptable for women.

In what follows, we test whether gender differences in health reporting can be partly ascribed to different social norms across men and women, as showing up in the workplace. In the literature, social norms are usually captured through the average corresponding characteristic - for example the average ideal weight in the obesity literature - in the reference group - see Etilé (2007) and Gil and Mora (2011). In our framework, the reference group is work colleagues. Following the standard methodology, social norms should be proxied by the average gender-specific health reporting behaviour in that group. Given that the European Working Conditions Survey that we use does not contain such direct information, we proxy gender-specific health-reporting norms by the gender composition of the group. We therefore hypothesise that reporting health symptoms and/or poor general health will be considered more legitimate in female-dominated work environments than in male-dominated or mixed

\footnotetext{
${ }^{2}$ Malaise symptoms include difficulties sleeping, nerves, always feeling tired, difficulties concentrating and worrying over every little thing.

${ }^{3}$ The Bem Sex Role Inventory is the most widely used and validated measure of gender-role orientation. It relies on individuals' evaluation of themselves through a series of adjectives and characteristics which are considered as culturally characteristic of either males or females - see Bem (1981).
} 
environments. In the rest of the paper, we test this assumption by estimating whether women (resp. men) report worse self-assessed health and/or more health problems when working in female (resp. male) dominated environments than in mixed environments.

\section{The econometric model}

As a first step, we estimate the effect of gender on self-reported health by probit: ${ }^{4}$

$$
\text { Health }_{i j s}^{*}=\alpha+\beta \text { Female }_{i j s}+X_{i j s} \gamma+D_{j}+D_{s}+u_{i j s}
$$

where Health $h_{i j s}^{*}$ denotes the latent health status of individual $i$ in country $j$ and industry $s$ :

$$
\left\{\begin{array}{l}
\text { Health }_{i j s}=1 \text { if } \text { Health }_{i j s}^{*}>0 \\
\text { Health }_{i j s}=0 \text { otherwise }
\end{array}\right.
$$

Female $_{i j s}$ is an indicator of gender, $X_{i j s}$ is a vector of individual and establishment-level controls including age, education, occupation, marital status, the number of children, establishment size and individual's tenure in the plant. $D_{j}$ and $D_{s}$ denote country and industry dummies respectively.

Once established that women systematically report poorer self-rated health than men, we investigate the potential role of social norms in explaining this pattern of results. To do so, we estimate the impact of the gender structure of individuals' work environment on the health outcomes that they report, for men and women separately. More specifically, for each gender group, we estimate the following probit model:

$$
\text { Health }_{i j s}^{*}=\alpha+X_{i j s} \gamma+\delta_{1} \text { Male_Env } v_{i j s}+\delta_{2} \text { Female_Env }_{i j s}+D_{j}+D_{s}+v_{i j s}
$$

where Male_Env (respectively Female_Env) is an indicator of a male (resp. female) dominated work environment ${ }^{5}$ - i.e. of an environment in which males (resp. females) are a majority. We interpret the marginal effects on the Male_Env and Female_Env variables as capturing the impact of gender-related social norms in the work environment. They indeed indicate how a work environment respectively dominated by men or women may affect selfreported health for males and females, all other things equal.

\footnotetext{
${ }^{4}$ All health outcomes in our data are binary variables except self-assessed health (rated from 1 to 5) and wellbeing (taking values from 0 to 4 ) for which we estimate ordered-probit models.

${ }^{5}$ The reference is a mixed-gender environment.
} 
One problem when estimating equation (2) arises if male-dominated work environments are systematically of better (or worse) quality than female-dominated environments. In this case, our estimates suffer from an omitted-variable bias and we may attribute to social pressure health-reporting behaviours that are, in fact, due to differences in job quality. In order to overcome this problem, we take advantage of the very rich information on job quality available in our data - see Section 4 - and estimate a more complete specification in which we control for 13 indices of job quality covering a uniquely large range of job characteristics and working conditions - see Data Appendix:

Health $_{i j s}^{*}=\alpha+X_{i j s} \gamma+\delta_{1}$ Male_Env $_{i j s}+\delta_{2}$ Female_Env $_{i j s}+\operatorname{JobQual}_{i j s} \vartheta+D_{j}+D_{s}+$ $\epsilon_{i j s}$

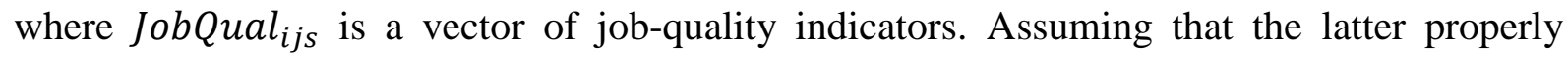
control for systematic differences in the quality of work across male and female-dominated work environments, we can validly interpret $\hat{\delta}_{1}$ and $\hat{\delta}_{2}$ as capturing the "true" effect of gender-related social pressure in the work environment on self-reported health outcomes.

\section{Data}

\section{The European Working Conditions Survey}

The data we use come from the fifth wave of the European Working Conditions Survey (EWCS). This survey has been commissioned by the European Foundation for the Improvement of Living and Working Conditions and carried out in 2010. Face-to-face interviews were conducted with persons in employment in the 28 member states as well as in Norway, Macedonia, Turkey, Albania, Kosovo and Montenegro. The dataset contains detailed information on individual working conditions, earnings, work-life balance, hours worked and work organisation. It also covers several aspects of health as well as demographic and socioeconomic characteristics.

Given that the focus of our analysis is on the health impact of social norms as measured in the work environment, we consider only salaried individuals. We exclude employees for which we do not have information on the sector in which they are employed and those working in agriculture, mining and fuel production because of scarce data reliability. ${ }^{6}$ Only individuals

\footnotetext{
${ }^{6}$ Overall, the sectors included in our study correspond to sectors 15 to 95 in the Nomenclature of Economic Activities in the European Union (NACE Rev. 1 classification).
} 
aged 65 and below are included in our study. Our final sample consists of 30,124 individuals from 30 countries.

\section{Variables}

Individual health is measured using several self-reported variables. The first one is selfassessed health which is rated on a 1 to 5 scale: very bad, bad, fair, good and very good. There is evidence in the literature that self-rated health is a good indicator of individual overall health (Ferrie et al., 1995). It has been found to be a good predictor of mortality even after controlling for more objective measures of health (Idler and Kasl, 1991; Idler and Benyamini, 1997; Bath, 2003). However, the probability of reporting good or bad health may suffer from individual reporting heterogeneity (Etilé and Milcent, 2006; Tubeuf et al., 2008). So, we also use more precise measures of health capturing specific diseases or symptoms. In the EWCS database, respondents are asked whether they have suffered over the last 12 months from either hearing problems, backache, skin problems, muscular pain in shoulders, neck and/or upper limbs, muscular pain in lower limbs, headache or eyestrain, stomach ache, respiratory difficulties, cardiovascular diseases, depression or anxiety, overall fatigue, or insomnia. For each of these health disorders, we build a corresponding dummy variable taking value 1 if the individual suffered from it, 0 otherwise. We also use information about individuals' wellbeing. We build dummy variables equal to 1 if the individual answers 'All the time', 'Most of the time' or 'More than half of the time' to the following assertions: '[Over the past 2 weeks] I have felt cheerful and in good spirits'; 'I have felt calm and relaxed'; 'I woke up feeling fresh and rested'; 'My daily life has been filled with things that interest me'. These dummy variables are equal to 0 otherwise. We then aggregate them into a well-being indicator taking values 0 to 4 .

Our baseline specification includes individual and plant characteristics. More specifically, we control for age (8 classes), education (higher education, secondary education and below secondary), occupation (managers and professionals, technicians and supervisors, white collars and blue collars), marital status (presence of a spouse or partner), the number of children (entered as a continuous variable $)^{7}$, establishment size ( 5 classes), individual's tenure in the plant, industry and country dummies.

The gender structure of the work environment is assessed using the answer to the following question: "At your place of work are workers with the same job title as you mostly men,

\footnotetext{
${ }^{7}$ As a robustness check, we control for a dummy variable indicating whether the individual has two children or more, rather than for the number of children entered as a continuous variable.
} 
mostly women, more or less equal numbers of men and women?". We capture a male environment with a dummy variable equal to 1 if the individual answers "Mostly men" (0 otherwise) and a female environment with a dummy variable equal to 1 if she answers "Mostly women" (0 otherwise). Answers indicating "More or less equal numbers of men and women" are considered as capturing a mixed-gender environment. Note that these variables capture gender-related social pressure arising from interactions with the closest colleagues, insofar as they regard individuals with the same job title.

Our complete specification includes indicators of job quality. As suggested by the OECD (2013), we consider several dimensions of it: job quality is measured on the basis of 47 raw indicators that we aggregate into 13 variables in most specifications. Most variables are indices taking values 0 to 10 and are the normalised sum of a specific number of raw indicators - see Data Appendix. The first index captures painful physical working conditions such as working at high or low temperature, being exposed to vibrations from tools or machinery, loud noise, smokes or fumes, vapours, painful positions, handling or being in direct contact with chemical products or materials that can be infectious, lifting or moving people, carrying heavy loads, standing and performing repetitive movements. Other dimensions of job quality include: work pressure (working more than 48 hours a week, not having enough time to get the job done, working at high speed or to tight deadlines and commuting more than one hour a day), work harassment (being the object of verbal abuse, threats or bullying), emotional stress (carrying out tasks that are in conflict with one's personal values, having to hide one's feelings, handling angry clients), decision latitude (ability to choose the order of tasks, the methods and speed of work, ability to make a break when one wishes and to apply one's own ideas in one's work), learning opportunities (benefitting from on-the-job training and/or employer-paid or provided training, having the opportunity of learning new things and solving unforeseen problems), task clarity (knowing what is expected from one's work, getting feedback from one's supervisor about one's work and having a supervisor who is good at planning the work), managerial support (getting help from one's supervisor, having a supervisor who respects you, who is good at resolving conflicts and who encourages you to participate in important decisions), support from colleagues (getting help from colleagues, feeling "at home" in the organisation, having good friends at work). Eventually, our job quality controls also include job insecurity (perceived risk of losing one's job in the next six months, ranging from 1 to 5), monthly earnings (grouped into quintiles), employability (ability to find a new job easily if one should lose the 
current one, ranging from 1 to 5) and work-family balance (how well working hours fit with family and social commitments, ranging from 0 to 3 ).

\section{Descriptive statistics}

Descriptive statistics are provided in Appendix Tables A1-A3 and A5-A6. In our sample, women are slightly older than men, a smaller proportion of them live in couple and they have a marginally more children - see Appendix Table A1. They are also more educated and more concentrated in higher-skilled and white-collar occupations, work in smaller establishments and have lower tenure than men on average. When considering health variables, women appear to report poorer health in general but they also report specific health symptoms more frequently, except for hearing problems - see Appendix Table A2. They also report slightly lower levels of well-being. As regards job quality, women seem to benefit from a better work environment in terms of physical working conditions, support from managers and colleagues and work-family balance, as well as reduced work pressure and job insecurity. In contrast, they suffer more than men from work harassment and emotional stress and report lower decision latitude, learning opportunities and employability.

The largest proportion of respondents in our sample comes from Belgium, France and Germany - see Appendix Table A5 - while the smallest group are the Greeks. As regards industries, those with the greatest share of employees are health and social work, education and retail trade - see Appendix Table A6. Finally, men and women-dominated environments turn out to be highly polarised - see Appendix Table A3: men represent $87 \%$ of employees in the former while women represent $89 \%$ in the latter. In contrast, mixed-gender environments are clearly balanced with $56 \%$ of women and $44 \%$ of men.

\section{Results}

\section{The gender gap in self-reported health}

We first estimate the impact of gender on self-reported health controlling for a series of individual and establishment-level characteristics - see equation (1). The results presented in Table 1 suggest that women systematically report poorer health than men. They report lower self-assessed health and well-being and declare suffering from specific health symptoms more frequently than men do. This is the case for all the health outcomes we consider (hearing problems, skin problems, backache, muscular pain in upper or lower limbs, headache and eyestrain, stomach ache, respiratory difficulties, depression and anxiety, fatigue and 
insomnia) and the difference with men is always significant at the $1 \%$ level. The only exceptions are hearing problems which women report less frequently than men do and cardiovascular diseases for which there is no significant difference across gender.

When estimating all health outcomes, we control for several individual characteristics. The marginal effects on these control variables are shown for one specific health outcome namely self-assessed health - in Appendix Table A4. As expected, age turns out to have a negative impact on health; individuals with higher levels of education are in better health as are employees in more highly-skilled occupations. Conditional on these variables, neither the individual's marital status, nor the number of children nor tenure appear to have any significant effect on health. ${ }^{8}$ In contrast, working in a small establishment (less than 10 employees) seems to be positively correlated with health.

When considering the results in Table 1, it may be interesting to notice that women systematically report a lower health status than men for all outcomes that can be, to some extent, self-diagnosed - except hearing problems: self-assessed health, more health "problems" (related to skin or respiration), more pain (back ache, muscular pain, headache, stomach ache), more mental health problems (depression and anxiety, fatigue and insomnia) and lower general well-being. In contrast, there is no difference between men and women for cardiovascular diseases, which is arguably the health problem most likely to have been diagnosed by a physician. This suggests that, beyond differences in actual health across genders, there may also be differences in reporting with women being systematically more pessimistic about their health than men are. In what follows, we investigate the potential role of social norms in the work environment in shaping health-reporting differences across genders.

\section{Social norms and gender differences in self-reported health}

We capture social norms in the work environment by the gender structure of this environment. More specifically, we estimate equation (2) separately for women and men and interpret the impact of working in a men or women-dominated environment as a proxy of the role of social norms in that environment.

\footnotetext{
${ }^{8}$ This result remains unchanged if we control for a dummy variable indicating whether individuals have two children or more rather than including the total number of children as a continuous variable. The marginal effect of the gender variable (women) on self-assessed health is also unchanged: -0.043 with standard error 0.006 .
} 
When considering the sample of women, differences in health-reporting behaviours are striking across types of work environments: women working in male-dominated environments do not report worse health status than women working in mixed-gender environments - see Table 2 - col (1). In contrast, women working in environments where women are a majority report significantly worse self-assessed health and general well-being, as well as more frequent specific health problems. This is the case for hearing difficulties, skin problems, backache, muscular pain in upper and lower limbs and overall fatigue (all of them at the $1 \%$ significance level) but also, for headaches or eyestrain, respiratory difficulties, cardiovascular diseases, depression and anxiety (at the 5\% level) and insomnia (at the 10\% level) - see Table $2-\operatorname{col}(2)$. This pattern of results is found, to a lower extent, for men too. Men working in male-dominated environments report fewer headaches and eyestrain than men working in mixed-gender environments - see Table 2 - col (3). In contrast, men working in femaledominated environments report more specific health problems such as skin problems, backache, muscular pain in upper limbs (at the 1\% significant level) as well as depression and anxiety, insomnia (at the 5\% level), muscular pain in lower limbs and overall fatigue (at the $10 \%$ level) - see Table 2 - col (4). The only exceptions have to do with backache and muscular pain in upper and lower limbs which men too tend to report more frequently when employed in male-dominated environments.

One explanation for this overall pattern of results is that health-reporting behaviours are affected by social norms. In environments where women are a majority, it would be "legitimate" to mention health problems, so that both men and women would report more of them when asked in a survey, whereas, in environments in which men are a majority, this would not be the case. Of course, a competing explanation would be that work is more harmful to health in female-dominated than in male-dominated work environments so that all individuals - whatever their gender - tend to report poorer health in the former than in the latter. We test this hypothesis by re-estimating equation (2) controlling for a very large array of job quality indicators. The specification presented in Table 3 includes 13 aggregate indices of job quality covering aspects as varied as painful physical working conditions, work harassment, decision latitude, learning opportunities, task clarity, managerial support and support from colleagues, work pressure, emotional stress, employability, job insecurity, workfamily balance and earnings. As evidenced in Table 3, our main results are robust to the inclusion of these additional controls. Women working in male-dominated environments do not report worse health status than women working in mixed-gender environments - see col 
(1). In contrast, women working in environments where females are a majority report more skin problems, backache, muscular pain both in upper and lower limbs and overall fatigue as well as lower general well-being (all of them at least at the 5\% significance level) - see col (2). The pattern of results obtained for men goes in the same direction and is even clearer than in Table 2: men working in male-dominated environments report, if anything, fewer health symptoms than men working in mixed-gender environments: this is the case for headaches and eyestrain, cardiovascular diseases and depression and anxiety - see col (3). In contrast, men working in female-dominated environments report more health symptoms, in particular skin problems and backache - see col (4). These results are also robust to controlling for the 47 raw job quality indicators that we have in our data instead of the 13 aggregate indices used in Table $3 .{ }^{9}$

This suggests that the differences in self-reported health observed across male and femaledominated work environments cannot be entirely ascribed to differences in job quality. At least part of it is due to social norms, which make it more legitimate to discuss and hence report health problems in female than in male-dominated environments.

\section{Discussion and Conclusion}

This study analyses the role of social norms associated with specific gender environments in the workplace in accounting for differences in health-reporting behaviours across men and women. As a first step, we provide evidence that women report poorer health than men on all health outcomes except hearing problems and cardiovascular diseases. This contributes to the literature showing significant differences in reported morbidity across genders. This difference is still a puzzle and one possible explanation is that health-reporting behaviour varies across genders. Results by Spiers et al. (2003) go in this direction since they find that self-rated health is less strongly associated with mortality for women than for men and that this is unlikely to be explained by differences in the nature of their physical health problems.

In the second part of this study, we investigate to what extent the difference in self-reported health between men and women may be partly ascribed to gender-based social norms as they materialise in the work environment. We capture social norms by the gender composition of the work environment and show that men and women employed in workplaces where women are a majority tend to report worse health than individuals employed in mixed-gender work

\footnotetext{
${ }^{9}$ Results are available from the authors upon request.
} 
environments. The opposite holds for men employed in male-dominated environments: they report fewer health symptoms than men employed in mixed-gender environments. We interpret our results are suggesting that reporting health symptoms is more legitimate in female than in male-dominated work environments.

Our results contrast with Case and Paxson's (2005) who conclude that health-reporting behaviours do not differ across genders based on the observation that men and women with the same chronic conditions report the same self-rated health. However, most of the chronic conditions they consider are also self-reported and may hence be subject to some form of bias (Bago d'Uva et al, 2008; Johnston et al, 2009). Some of them have most likely been diagnosed by a doctor. This is the case of the various types of cancers (skin, stomach, reproductive, respiratory) or of cardiovascular diseases, emphysema or diabetes. However, other chronic conditions may be reported in a different way by men and women. This is the case for headaches, other pain, arthritis, lung problems, vision problems or depression. For the latter, the fact that they be correlated in the same way with general self-rated health does not prevent men and women from having different reporting behaviours since women may over-report both poor self-rated health and chronic conditions.

A limitation of our study lies in the fact that we do not directly measure gender-specific health-reporting social norms. The strategy we adopt is to proxy them by the gender composition of the work environment. A key advantage of the EWCS data is that it contains a wealth of information on job quality which allows us to rule out that female-dominated work environments could be of poorer quality which would account for worse reported health. However, one of its drawbacks is the lack of information - beyond its gender composition on the characteristics of the work environment. More generally, information on the characteristics of individuals' work environment is usually scarce in available survey data. Collecting such information is however a necessity to allow researchers to investigate the role of social norms in shaping health - and more generally social - attitudes as well as interpersonal relationships in the workplace. 


\section{References}

Akerlof G., Kranton R. 2000. "Economics and Identity", Quarterly Journal of Economics, 115(3), 715-753.

Arber S. and Cooper H. 1999. "Gender differences in health in later life: the new paradox?", Social Science \& Medicine, 48(1), 61-76

Bago d'Uva T., E. van Doorslaer, M. Lindeboom and O. O'Donnell. 2008. "Does Reporting Heterogeneity Bias the Measurement of Health Disparities?", Health Economics, 17(3), 351375.

Bago d'Uva T, M Lindeboom, O O'Donnell and E van Doorslaer. 2011. "Education-related Inequity in Health Care with Heterogeneous Reporting of Health", Journal of the Royal Statistical Society, Series A, 174(3), 639-664.

Bath PA. 2003. "Differences between older men and women in the self-rated health-mortality relationship", The Gerontologist, 43(3), 387-395.

Bem S. 1981. Bem Sex-role Inventory Professional Manual, Consulting Psychologist Press, Palo-Alto, CA.

Blanchflower D, B. Van Landeghem and A. Oswald. 2009. "Imitative Obesity and Relative Utility", Journal of the European Economic Association, 7(2-3), 528-538.

Brock W., Durlauf S. 2001. "Discrete Choice with Social Interactions", The Review of Economic Studies, 68(2), 235-260.

Case A., Paxson C. 2005. "Sex Differences in Morbidity and Mortality", Demography, 42(2), 189-214.

Christakis N. and J. Fowler. 2007. "The Spread of Obesity in Large Social Network over 32 years", New England Journal of Medicine, 357(4), 370-379.

Cohen-Cole E. and J. Fletcher. 2008. "Is obesity contagious? Social networks vs. environmental factors in the obesity epidemic", Journal of Health Economics, 27(5), 13821387.

Emslie C., Hunt K. and Macintyre S. 1999. "Problematizing gender, work and health: the relationship between gender, occupational grade, working conditions and minor morbidity in full-time bank employees", Social Science \&Medicine, 48(1), 33-48.

Emslie C., Fuhrer R., Hunt K. Macintyre S., Shipley M. and Stansfeld S. 2002. "Gender differences in mental health: evidence from three organisations", Social Science \& Medicine, 54(4), 621-624.

Etilé F, Milcent C. 2006. "Income-related reporting heterogeneity in self-assessed health: evidence from France", Health Economics, 15(9), 965-981.

Etilé F. 2007. "Social norms, ideal body weight and food attitudes", Health Economics, 16(9), 945-966.

Ferrie JE, Shipley MJ, Marmot MG, Stansfeld S, Smith GD. 1995. "Health effects of anticipation of job change and nonemployment: longitudinal data from the Whitehall II study", British Medical Journal, 311(7015), 1264-1269.

Fowler J. and N. Christakis. 2008. "Estimating peer effects on health in social networks: a response to Cohen-Cole and Fletcher; Trogdon, Nonnemaker, Pais", Journal of Health 
Economics, 27(5), 1400-1405.

Gil J. and T. Mora. 2011. "The determinants of misreporting weight and height: the role of social norms", Economics and Human Biology, 9(1), 78-91.

Halliday T. and S. Kwak. 2009. "Weight gain in adolescents and their peers", Economics and Human Biology, 7(2), 181-190.

Hibbard J. and Pope C. 1983. "Gender Roles, Illness Orientation and Use of Medical Services", Social Science \& Medicine, 17(3), 129-137.

Hibbard J. and Pope C. 1986. "Another look at sex differences in the use of medical care: illness orientation and the types of morbidities for which services are used", Women \& Health, 11(2), 21-36.

Hunt K. and Annandale E. 1999. "Relocating gender and morbidity: examining men's and women's health in contemporary Western societies. Introduction to Special Issue on Gender and Health", Social Science \& Medicine, 48(1), 1-5.

Idler EL, Benyamini Y. 1997. "Self-rated health and mortality: a review of twenty-seven community studies", Journal of Health and Social Behavior, 38(1), 21-37.

Idler EL, Kasl S. 1991. "Health perceptions and survival: do global evaluations of health status really predict mortality?", Journal of Gerontology, 46(2), 55-65.

Johnston D. C. Propper and M. Shields. 2009. "Comparing subjective and objective measures of health: Evidence from hypertension for the income/health gradient", Journal of Health Economics, 28(3), 540-552.

Kessler R.C., Brown R.L. and Broman C.L. 1981. "Sex differences in Psychiatric HelpSeeking: Evidence from Four Large-Scale Surveys", Journal of Health and Social Behavior, 22(1), 49-64.

Lahelma E., Martikainen P., Rahkonen O. and Silventoinen K. 1999. "Gender differences in illhealth in Finland: patterns, magnitude and change", Social Science \& Medicine, 48(1), 7-19.

Lindeboom M. and E. van Doorslaer. 2004. "Cut-point shift and index shift in self-reported health", Journal of Health Economics, 23(6), 1083-1099.

Macintyre S. 1993. "Gender differences in the perceptions of common cold symptoms", Social Science \& Medicine, 36(1), 15-20.

Mahalik J.R., Burns S.M. and Syzdek M. 2007. "Masculinity and perceived normative health behaviors as predictors of men's health behaviors", Social Science\&Medicine, 64(11), 22012209.

Manski C. 1993. "Identification of endogenous social effects: the reflection problem", The Review of Economics Studies, 60(3), 531-542.

Marshall J.R. and Funch D.P. 1986. "Gender and illness behavior among colorectal cancer patients"; Women \& Health, 11(3-4), 67-82.

OECD. 2013. How's Life? Measuring Well-Being, OECD: Paris, 216p.

Popay J., Bartley M. and Owen C. 1993. "Gender inequalities in health: social position, affective disorders and minor physical morbidity", Social Science \& Medicine, 36(1), 21-32.

Powdthavee N. 2009. "Ill-health as a household norm: Evidence from other people's health problems", Social Science \& Medicine, 68(2), 251-259.

Raspe H, A. Hueppe and H. Neuhauser. 2008. "Back pain, a communicable disease?", 
International Journal of Epidemiology, 37(1), 69-74.

Schneider U., Pfarr C., Schneider B. and Ulrich V. 2012. "I feel good! Gender differences and reporting heterogeneity in self-assessed health", European Journal of Health Economics, 13(3), 251-265.

Trogdon J, J. Nonnemaker and J. Pais. 2008. "Peer effects in adolescent overweight", Journal of Health Economics, 27(5), 1388-1399.

Verbrugge L. 1989. "The twain meet: empirical explanations of sex differences in health and mortality", Journal of Health and Social Behavior, 30(3), 282-304.

Zunzunegui M-V., Alvarado B-E., Béland F. and Vissandjee B. 2009. "Explaining health differences between men and women in later life: A cross-city comparison in Latin America and the Caribbean", Social Science \& Medicine, 68(2), 235-242. 


\section{Tables}

Table 1 - Marginal Effects of being a woman

\begin{tabular}{lll}
\hline Health outcomes & $\begin{array}{c}\text { Marginal } \\
\text { Effects }\end{array}$ & $\begin{array}{c}\text { Standard } \\
\text { errors }\end{array}$ \\
\hline \hline Self-assessed health & $-0.043^{* * *}$ & $(0.006)$ \\
Hearing problems & $-0.014^{* * *}$ & $(0.004)$ \\
Skin problems & $0.033^{* * *}$ & $(0.005)$ \\
Backache & $0.076^{* * *}$ & $(0.009)$ \\
Muscular pains in upper limbs & $0.111^{* * *}$ & $(0.009)$ \\
Muscular pains in lower limbs & $0.045^{* * *}$ & $(0.008)$ \\
Headache/eyestrain & $0.138^{* * *}$ & $(0.008)$ \\
Stomach ache & $0.028^{* * *}$ & $(0.006)$ \\
Respiratory difficulties & $0.017 * * *$ & $(0.004)$ \\
Cardiovascular diseases & -0.003 & $(0.004)$ \\
Depression and anxiety & $0.031^{* * *}$ & $(0.006)$ \\
Overall fatigue & $0.081^{* * *}$ & $(0.008)$ \\
Insomnia & $0.050^{* * *}$ & $(0.007)$ \\
Well-being & $-0.064^{* * *}$ & $(0.008)$ \\
\hline Observations & 14750 &
\end{tabular}

Observations 14750

Notes: (1) Control variables include: age, education, occupation, marital status, number of children, establishment size, tenure, industry and country dummies. (2) All estimates are obtained by simple probits except for self-assessed health and well-being for which they are obtained by ordered probits. (3) Robust standard errors are in parentheses ***: Significant at the $1 \%$ level, **: Significant at the 5\% level, *: Significant at the $10 \%$ level 
Table 2 - Marginal effects of male and female-dominated work environments

\begin{tabular}{|c|c|c|c|c|}
\hline \multirow[b]{2}{*}{ Health outcomes } & \multicolumn{2}{|c|}{$\begin{array}{l}\text { Subsample: } \\
\text { Women }\end{array}$} & \multicolumn{2}{|c|}{$\begin{array}{c}\text { Subsample: } \\
\text { Men }\end{array}$} \\
\hline & $\begin{array}{c}\text { Male- } \\
\text { dominated } \\
\text { Environment } \\
\text { (ref. mixed- } \\
\text { gender } \\
\text { environment) } \\
\text { (1) }\end{array}$ & $\begin{array}{l}\text { Female- } \\
\text { dominated } \\
\text { Environment } \\
\text { (ref. mixed- } \\
\text { gender } \\
\text { environment) } \\
\text { (2) }\end{array}$ & $\begin{array}{c}\text { Male- } \\
\text { dominated } \\
\text { Environment } \\
\text { (ref. mixed- } \\
\text { gender } \\
\text { environment) } \\
\text { (3) }\end{array}$ & $\begin{array}{l}\text { Female- } \\
\text { dominated } \\
\text { Environment } \\
\text { (ref. mixed- } \\
\text { gender } \\
\text { environment) } \\
\text { (4) }\end{array}$ \\
\hline Self-assessed health & $\begin{array}{l}-0.001 \\
(0.010)\end{array}$ & $\begin{array}{c}-0.017 * * * \\
(0.006)\end{array}$ & $\begin{array}{l}-0.011 \\
(0.007)\end{array}$ & $\begin{array}{l}-0.009 \\
(0.012)\end{array}$ \\
\hline Hearing problems & $\begin{array}{l}-0.000 \\
(0.007)\end{array}$ & $\begin{array}{c}0.011 * * * \\
(0.004)\end{array}$ & $\begin{array}{c}0.002 \\
(0.006)\end{array}$ & $\begin{array}{l}-0.001 \\
(0.009)\end{array}$ \\
\hline Skin problems & $\begin{array}{c}0.000 \\
(0.010)\end{array}$ & $\begin{array}{c}0.024 * * * \\
(0.006)\end{array}$ & $\begin{array}{c}0.007 \\
(0.006)\end{array}$ & $\begin{array}{c}0.029 * * * \\
(0.009)\end{array}$ \\
\hline Backache & $\begin{array}{c}0.023 \\
(0.016)\end{array}$ & $\begin{array}{c}0.054 * * * \\
(0.009)\end{array}$ & $\begin{array}{c}0.041 * * * \\
(0.010)\end{array}$ & $\begin{array}{c}0.044 * * * \\
(0.017)\end{array}$ \\
\hline Muscular pain in upper limbs & $\begin{array}{c}0.015 \\
(0.016)\end{array}$ & $\begin{array}{c}0.055^{* * *} * \\
(0.009)\end{array}$ & $\begin{array}{c}0.039 * * * \\
(0.010)\end{array}$ & $\begin{array}{c}0.056 \text { *** } \\
(0.017)\end{array}$ \\
\hline Muscular pain in lower limbs & $\begin{array}{l}-0.003 \\
(0.015)\end{array}$ & $\begin{array}{c}0.054 * * * \\
(0.008)\end{array}$ & $\begin{array}{c}0.034 * * * \\
(0.010)\end{array}$ & $\begin{array}{l}0.029 * \\
(0.016)\end{array}$ \\
\hline Headache / eyestrain & $\begin{array}{l}-0.001 \\
(0.016)\end{array}$ & $\begin{array}{c}0.020 * * \\
(0.009)\end{array}$ & $\begin{array}{c}-0.019^{*} \\
(0.010)\end{array}$ & $\begin{array}{c}0.016 \\
(0.016)\end{array}$ \\
\hline Stomach ache & $\begin{array}{c}0.009 \\
(0.011)\end{array}$ & $\begin{array}{c}0.004 \\
(0.007)\end{array}$ & $\begin{array}{c}0.006 \\
(0.007)\end{array}$ & $\begin{array}{c}0.016 \\
(0.011)\end{array}$ \\
\hline Respiratory difficulties & $\begin{array}{l}-0.000 \\
(0.008)\end{array}$ & $\begin{array}{c}0.011^{* *} \\
(0.005)\end{array}$ & $\begin{array}{c}0.002 \\
(0.005)\end{array}$ & $\begin{array}{c}0.006 \\
(0.008)\end{array}$ \\
\hline Cardiovascular diseases & $\begin{array}{l}-0.005 \\
(0.008)\end{array}$ & $\begin{array}{c}0.009 * * \\
(0.004)\end{array}$ & $\begin{array}{l}-0.007 \\
(0.005)\end{array}$ & $\begin{array}{c}0.010 \\
(0.007)\end{array}$ \\
\hline Depression and anxiety & $\begin{array}{c}0.008 \\
(0.011)\end{array}$ & $\begin{array}{c}0.013 * * \\
(0.006)\end{array}$ & $\begin{array}{l}-0.002 \\
(0.006)\end{array}$ & $\begin{array}{c}0.023^{* *} \\
(0.009)\end{array}$ \\
\hline Overall fatigue & $\begin{array}{c}0.014 \\
(0.015)\end{array}$ & $\begin{array}{c}0.034 * * * \\
(0.009)\end{array}$ & $\begin{array}{c}0.015 \\
(0.010)\end{array}$ & $\begin{array}{l}0.028^{*} \\
(0.016)\end{array}$ \\
\hline Insomnia & $\begin{array}{c}0.013 \\
(0.013)\end{array}$ & $\begin{array}{l}0.015^{*} \\
(0.008)\end{array}$ & $\begin{array}{c}0.006 \\
(0.008)\end{array}$ & $\begin{array}{c}0.027 * * \\
(0.013)\end{array}$ \\
\hline Well being & $\begin{array}{l}-0.020 \\
(0.014)\end{array}$ & $\begin{array}{c}-0.031 * * * \\
(0.008)\end{array}$ & $\begin{array}{l}-0.009 \\
(0.010)\end{array}$ & $\begin{array}{l}-0.006 \\
(0.015)\end{array}$ \\
\hline
\end{tabular}

Notes: (1) The reference category is mixed-gender environment (2) Control variables include: age, education, occupation, marital status, number of children, establishment size, tenure, industry and country dummies. (3) All estimates are obtained by simple probits except for self-assessed health and well-being for which they are obtained by ordered probits. (4) Robust standard errors are in parentheses ***: Significant at the 1\% level, **: Significant at the 5\% level, *: Significant at the $10 \%$ level 
Table 3 - Marginal effects of male and female-dominated work environments Controlling for job quality

\begin{tabular}{|c|c|c|c|c|}
\hline \multirow[b]{2}{*}{ Health outcomes } & \multicolumn{2}{|c|}{$\begin{array}{l}\text { Subsample: } \\
\text { Women }\end{array}$} & \multicolumn{2}{|c|}{$\begin{array}{c}\text { Subsample: } \\
\text { Men }\end{array}$} \\
\hline & $\begin{array}{c}\text { Male- } \\
\text { dominated } \\
\text { Environment } \\
\text { (ref. mixed- } \\
\text { gender } \\
\text { environment) } \\
\text { (1) }\end{array}$ & $\begin{array}{l}\text { Female- } \\
\text { dominated } \\
\text { Environment } \\
\text { (ref. mixed- } \\
\text { gender } \\
\text { environment) } \\
\text { (2) }\end{array}$ & $\begin{array}{c}\text { Male- } \\
\text { dominated } \\
\text { Environment } \\
\text { (ref. mixed- } \\
\text { gender } \\
\text { environment) } \\
\text { (3) }\end{array}$ & $\begin{array}{c}\text { Female- } \\
\text { dominated } \\
\text { Environment } \\
\text { (ref. mixed- } \\
\text { gender } \\
\text { environment) } \\
\text { (4) }\end{array}$ \\
\hline Self-assessed health & $\begin{array}{c}0.014 \\
(0.012)\end{array}$ & $\begin{array}{l}-0.009 \\
(0.008)\end{array}$ & $\begin{array}{c}0.001 \\
(0.009)\end{array}$ & $\begin{array}{l}-0.015 \\
(0.015)\end{array}$ \\
\hline Hearing problems & $\begin{array}{l}-0.002 \\
(0.009)\end{array}$ & $\begin{array}{c}0.009 \\
(0.006)\end{array}$ & $\begin{array}{c}0.002 \\
(0.008)\end{array}$ & $\begin{array}{l}-0.002 \\
(0.012)\end{array}$ \\
\hline Skin problems & $\begin{array}{l}-0.010 \\
(0.013)\end{array}$ & $\begin{array}{c}0.022 * * * \\
(0.008)\end{array}$ & $\begin{array}{c}0.003 \\
(0.007)\end{array}$ & $\begin{array}{c}0.030 * * * \\
(0.011)\end{array}$ \\
\hline Backache & $\begin{array}{c}0.001 \\
(0.019)\end{array}$ & $\begin{array}{c}0.038 * * * \\
(0.012)\end{array}$ & $\begin{array}{c}0.011 \\
(0.013)\end{array}$ & $\begin{array}{l}0.036^{*} \\
(0.021)\end{array}$ \\
\hline Muscular pain in upper limbs & $\begin{array}{l}-0.006 \\
(0.019)\end{array}$ & $\begin{array}{c}0.031 * * * \\
(0.012)\end{array}$ & $\begin{array}{c}0.004 \\
(0.013)\end{array}$ & $\begin{array}{c}0.041 * * \\
(0.021)\end{array}$ \\
\hline Muscular pain in lower limbs & $\begin{array}{l}-0.030 \\
(0.018)\end{array}$ & $\begin{array}{c}0.034 * * * \\
(0.011)\end{array}$ & $\begin{array}{c}0.011 \\
(0.012)\end{array}$ & $\begin{array}{c}0.023 \\
(0.019)\end{array}$ \\
\hline Headache / eyestrain & $\begin{array}{l}-0.006 \\
(0.020)\end{array}$ & $\begin{array}{c}0.003 \\
(0.012)\end{array}$ & $\begin{array}{c}-0.042 * * * \\
(0.013)\end{array}$ & $\begin{array}{c}0.016 \\
(0.020)\end{array}$ \\
\hline Stomach ache & $\begin{array}{l}-0.002 \\
(0.014)\end{array}$ & $\begin{array}{c}0.009 \\
(0.009)\end{array}$ & $\begin{array}{c}0.003 \\
(0.009)\end{array}$ & $\begin{array}{c}0.014 \\
(0.014)\end{array}$ \\
\hline Respiratory difficulties & $\begin{array}{l}-0.007 \\
(0.011)\end{array}$ & $\begin{array}{c}0.005 \\
(0.006)\end{array}$ & $\begin{array}{l}-0.003 \\
(0.007)\end{array}$ & $\begin{array}{l}-0.003 \\
(0.010)\end{array}$ \\
\hline Cardiovascular diseases & $\begin{array}{l}-0.017 \\
(0.011)\end{array}$ & $\begin{array}{c}0.006 \\
(0.006)\end{array}$ & $\begin{array}{c}-0.017 * * * \\
(0.006)\end{array}$ & $\begin{array}{c}0.003 \\
(0.009)\end{array}$ \\
\hline Depression and anxiety & $\begin{array}{l}-0.006 \\
(0.013)\end{array}$ & $\begin{array}{c}0.010 \\
(0.008)\end{array}$ & $\begin{array}{c}-0.014 * \\
(0.007)\end{array}$ & $\begin{array}{c}0.013 \\
(0.011)\end{array}$ \\
\hline Overall fatigue & $\begin{array}{l}-0.011 \\
(0.019)\end{array}$ & $\begin{array}{c}0.024 * * \\
(0.011)\end{array}$ & $\begin{array}{c}0.008 \\
(0.013)\end{array}$ & $\begin{array}{c}0.021 \\
(0.020)\end{array}$ \\
\hline Insomnia & $\begin{array}{c}0.009 \\
(0.016)\end{array}$ & $\begin{array}{c}0.009 \\
(0.010)\end{array}$ & $\begin{array}{l}-0.005 \\
(0.010)\end{array}$ & $\begin{array}{c}0.020 \\
(0.016)\end{array}$ \\
\hline Well being & $\begin{array}{l}-0.003 \\
(0.017)\end{array}$ & $\begin{array}{c}-0.024 * * \\
(0.010)\end{array}$ & $\begin{array}{l}-0.001 \\
(0.012)\end{array}$ & $\begin{array}{c}0.006 \\
(0.019)\end{array}$ \\
\hline
\end{tabular}

Notes: (1) The reference category is mixed-gender environment (2) Control variables include: age, education, occupation, marital status, number of children, establishment size, tenure, industry and country dummies and 13 indicators of job quality: painful physical working conditions, work harassment, decision latitude, learning opportunities, task clarity, managerial support and support from colleagues, work pressure, emotional stress, employability, job insecurity, workfamily balance and earnings. (3) All estimates are obtained by simple probits except for self-assessed health and well-being for which they are obtained by ordered probits. (4) Robust standard errors are in parentheses ***: Significant at the $1 \%$ level, **: Significant at the $5 \%$ level, *: Significant at the $10 \%$ level. 


\section{Appendix Tables (for publication)}

Table A.1 - Descriptive statistics: individual and firm characteristics

\begin{tabular}{|c|c|c|c|c|c|c|}
\hline \multirow[t]{2}{*}{ Variables } & \multicolumn{2}{|c|}{ Whole sample } & \multicolumn{2}{|c|}{ Women } & \multicolumn{2}{|c|}{ Men } \\
\hline & Mean & $\begin{array}{l}\text { Standard } \\
\text { deviation }\end{array}$ & Mean & $\begin{array}{r}\text { Standard } \\
\text { deviation }\end{array}$ & Mean & $\begin{array}{l}\text { Standard } \\
\text { deviation }\end{array}$ \\
\hline \multicolumn{7}{|l|}{ Age } \\
\hline Between 15 and 24 & 0.082 & $(0.27)$ & 0.076 & $(0.26)$ & 0.089 & $(0.28)$ \\
\hline Between 25 and 30 & 0.143 & $(0.35)$ & 0.132 & $(0.34)$ & 0.156 & $(0.36)$ \\
\hline Between 31 and 35 & 0.125 & $(0.33)$ & 0.123 & $(0.33)$ & 0.126 & $(0.33)$ \\
\hline Between 36 and 40 & 0.141 & $(0.35)$ & 0.143 & $(0.35)$ & 0.138 & $(0.34)$ \\
\hline Between 41 and 45 & 0.136 & $(0.34)$ & 0.140 & $(0.35)$ & 0.132 & $(0.34)$ \\
\hline Between 46 and 50 & 0.137 & $(0.34)$ & 0.146 & $(0.35)$ & 0.126 & $(0.33)$ \\
\hline Between 51 and 55 & 0.118 & $(0.32)$ & 0.124 & $(0.33)$ & 0.112 & $(0.31)$ \\
\hline Between 56 and 65 & 0.118 & $(0.32)$ & 0.114 & $(0.32)$ & 0.121 & $(0.33)$ \\
\hline Couple & 0.663 & $(0.47)$ & 0.641 & $(0.48)$ & 0.686 & $(0.46)$ \\
\hline Number of children & 0.900 & $(1.05)$ & 0.963 & (1.03) & 0.859 & $(1.07)$ \\
\hline \multicolumn{7}{|l|}{ Education } \\
\hline Higher education & 0.362 & $(0.48)$ & 0.398 & $(0.49)$ & 0.322 & $(0.47)$ \\
\hline $\begin{array}{l}\text { Secondary } \\
\text { education }\end{array}$ & 0.397 & $(0.49)$ & 0.380 & $(0.49)$ & 0.415 & $(0.49)$ \\
\hline Below secondary & 0.241 & $(0.43)$ & 0.221 & $(0.41)$ & 0.262 & $(0.44)$ \\
\hline \multicolumn{7}{|l|}{ Occupation } \\
\hline $\begin{array}{l}\text { Managers and } \\
\text { professionals }\end{array}$ & 0.208 & $(0.41)$ & 0.224 & $(0.42)$ & 0.190 & $(0.39)$ \\
\hline Technicians & 0.160 & $(0.37)$ & 0.180 & $(0.38)$ & 0.138 & $(0.34)$ \\
\hline White collars & 0.314 & $(0.46)$ & 0.412 & $(0.49)$ & 0.205 & $(0.40)$ \\
\hline Blue collars & 0.318 & $(0.47)$ & 0.184 & $(0.39)$ & 0.466 & $(0.50)$ \\
\hline \multicolumn{7}{|l|}{ Tenure } \\
\hline Less than 1 year & 0.091 & $(0.29)$ & 0.091 & $(0.29)$ & 0.091 & $(0.29)$ \\
\hline 1 to 5 years & 0.377 & $(0.48)$ & 0.383 & $(0.49)$ & 0.371 & $(0.48)$ \\
\hline 5 to 10 years & 0.194 & $(0.40)$ & 0.202 & $(0.40)$ & 0.186 & $(0.39)$ \\
\hline More than 10 years & 0.337 & $(0.47)$ & 0.323 & $(0.47)$ & 0.352 & $(0.48)$ \\
\hline \multicolumn{7}{|l|}{ Establishment size } \\
\hline Less than 10 employees & 0.315 & $(0.46)$ & 0.343 & $(0.47)$ & 0.282 & $(0.45)$ \\
\hline 11 to 49 employees & 0.334 & $(0.47)$ & 0.333 & $(0.47)$ & 0.334 & $(0.47)$ \\
\hline 50 to 99 employees & 0.121 & $(0.33)$ & 0.118 & $(0.32)$ & 0.123 & $(0.33)$ \\
\hline 100 to 499 employees & 0.152 & $(0.36)$ & 0.137 & $(0.34)$ & 0.167 & $(0.37)$ \\
\hline $\begin{array}{c}\text { More than } 500 \\
\text { employees }\end{array}$ & 0.079 & $(0.27)$ & 0.068 & $(0.25)$ & 0.091 & $(0.29)$ \\
\hline
\end{tabular}


Table A.2 - Descriptive statistics: Health variables and job quality indicators

\begin{tabular}{|c|c|c|c|c|c|c|}
\hline \multirow[t]{2}{*}{ Variables } & \multicolumn{2}{|c|}{ Whole sample } & \multicolumn{2}{|c|}{ Women } & \multicolumn{2}{|c|}{ Men } \\
\hline & Mean & $\begin{array}{l}\text { Standard } \\
\text { deviation }\end{array}$ & Mean & $\begin{array}{l}\text { Standard } \\
\text { deviation }\end{array}$ & Mean & $\begin{array}{l}\text { Standard } \\
\text { deviation }\end{array}$ \\
\hline \multicolumn{7}{|l|}{ Health variables } \\
\hline \multicolumn{7}{|l|}{ Self-assessed health } \\
\hline Very good & 0.25 & $(0.43)$ & 0.23 & $(0.42)$ & 0.27 & $(0.44)$ \\
\hline Good & 0.51 & $(0.50)$ & 0.51 & $(0.50)$ & 0.51 & $(0.50)$ \\
\hline Fair & 0.21 & $(0.41)$ & 0.23 & $(0.42)$ & 0.19 & $(0.40)$ \\
\hline $\mathrm{Bad}$ & 0.02 & $(0.15)$ & 0.03 & $(0.16)$ & 0.02 & $(0.14)$ \\
\hline Very bad & 0.002 & $(0.05)$ & 0.002 & $(0.05)$ & 0.003 & $(0.05)$ \\
\hline \multicolumn{7}{|l|}{ Having specific health problems } \\
\hline Hearing problems & 0.06 & $(0.25)$ & 0.05 & $(0.22)$ & 0.08 & $(0.27)$ \\
\hline Skin problems & 0.09 & $(0.28)$ & 0.10 & $(0.30)$ & 0.07 & $(0.26)$ \\
\hline Backache & 0.46 & $(0.50)$ & 0.48 & $(0.50)$ & 0.44 & $(0.50)$ \\
\hline Muscular pain in upper limbs & 0.44 & $(0.50)$ & 0.48 & $(0.50)$ & 0.41 & $(0.49)$ \\
\hline Muscular pain in lower limbs & 0.32 & $(0.46)$ & 0.32 & $(0.47)$ & 0.31 & $(0.46)$ \\
\hline Headache/eyestrain & 0.41 & $(0.49)$ & 0.48 & $(0.50)$ & 0.34 & $(0.47)$ \\
\hline Stomach ache & 0.14 & $(0.34)$ & 0.15 & $(0.36)$ & 0.12 & $(0.32)$ \\
\hline Respiratory difficulties & 0.06 & $(0.25)$ & 0.07 & $(0.25)$ & 0.06 & $(0.24)$ \\
\hline Cardiovascular diseases & 0.06 & $(0.23)$ & 0.06 & $(0.24)$ & 0.05 & $(0.22)$ \\
\hline Depression and anxiety & 0.11 & $(0.32)$ & 0.14 & $(0.34)$ & 0.09 & $(0.29)$ \\
\hline Overall fatigue & 0.41 & $(0.49)$ & 0.44 & $(0.50)$ & 0.37 & $(0.48)$ \\
\hline Insomnia/sleep difficulties & 0.21 & $(0.40)$ & 0.23 & $(0.42)$ & 0.18 & $(0.38)$ \\
\hline \multicolumn{7}{|l|}{ Well-being indicator } \\
\hline 4 (complete well-being) & 0.55 & $(0.50)$ & 0.52 & $(0.50)$ & 0.57 & $(0.49)$ \\
\hline 3 & 0.18 & $(0.38)$ & 0.18 & $(0.39)$ & 0.18 & $(0.38)$ \\
\hline 2 & 0.11 & $(0.31)$ & 0.12 & $(0.32)$ & 0.10 & $(0.30)$ \\
\hline 1 & 0.07 & $(0.26)$ & 0.08 & $(0.27)$ & 0.07 & $(0.25)$ \\
\hline 0 & 0.09 & $(0.29)$ & 0.10 & $(0.30)$ & 0.08 & $(0.27)$ \\
\hline \multicolumn{7}{|l|}{ Job quality } \\
\hline $\begin{array}{l}\text { Painful physical working conditions } \\
\text { (indicator ranging from } 1 \text { to } 10 \text { ) }\end{array}$ & 2.05 & $(1.58)$ & 1.78 & $(1.36)$ & 2.34 & $(1.75)$ \\
\hline Work harassment (1 to 10$)$ & 0.75 & $(2.01)$ & 0.79 & $(2.06)$ & 0.70 & $(1.96)$ \\
\hline Decision latitude (1 to 10 ) & 5.83 & $(2.74)$ & 5.79 & $(2.68)$ & 5.88 & $(2.80)$ \\
\hline Learning opportunities ( 1 to 10 ) & 5.55 & $(3.05)$ & 5.52 & $(3.09)$ & 5.59 & $(2.99)$ \\
\hline Task clarity ( 1 to 10$)$ & 8.70 & $(1.61)$ & 8.73 & (1.59) & 8.68 & (1.64) \\
\hline Managerial support ( 1 to 10 ) & 7.48 & $(2.38)$ & 7.51 & $(2.40)$ & 7.44 & $(2.36)$ \\
\hline Support from colleagues ( 1 to 10 ) & 7.19 & $(1.83)$ & 7.21 & $(1.86)$ & 7.17 & $(1.80)$ \\
\hline Work pressure (1 to 10$)$ & 3.77 & $(2.36)$ & 3.58 & $(2.37)$ & 3.97 & $(2.33)$ \\
\hline Emotional stress (1 to 10$)$ & 2.60 & $(2.01)$ & 2.77 & $(2.02)$ & 2.41 & 1.99 \\
\hline Employability (1 to 5) & 2.67 & $(1.26)$ & 2.66 & $(1.27)$ & 2.69 & $(1.25)$ \\
\hline Job insecurity ( 1 to 5 ) & 2.31 & $(1.23)$ & 2.29 & $(1.23)$ & 2.33 & $(1.23)$ \\
\hline Work-family balance ( 0 to 3 ) & 2.09 & $(0.76)$ & 2.13 & $(0.74)$ & 2.04 & $(0.78)$ \\
\hline
\end{tabular}


Table A.3 - Gender breakdown, by type of work environment

\begin{tabular}{lccccccc}
\hline Variables & \multicolumn{2}{l}{$\begin{array}{l}\text { Men-dominated } \\
\text { Environment }\end{array}$} & \multicolumn{2}{l}{$\begin{array}{l}\text { Women- } \\
\text { dominated } \\
\text { Environment }\end{array}$} & \multicolumn{2}{l}{$\begin{array}{l}\text { Mixed-gender } \\
\text { Environment }\end{array}$} \\
\hline Mean & $\begin{array}{l}\text { Standard } \\
\text { deviation }\end{array}$ & \multicolumn{2}{l}{ Mean } & $\begin{array}{l}\text { Standard } \\
\text { deviation }\end{array}$ & Mean & $\begin{array}{l}\text { Standard } \\
\text { deviation }\end{array}$ \\
\hline \hline $\begin{array}{l}\text { Gender } \\
\text { Women }\end{array}$ & 0.12 & $(0.33)$ & 0.89 & $(0.31)$ & 0.56 & $(0.50)$ \\
Men & 0.87 & $(0.33)$ & 0.11 & $(0.31)$ & 0.44 & $(0.50)$ \\
\hline
\end{tabular}

Table A.4 - Self-assessed health (ordered probit) - average marginal effects on all control variables Dependent variable: Self-Assessed Health

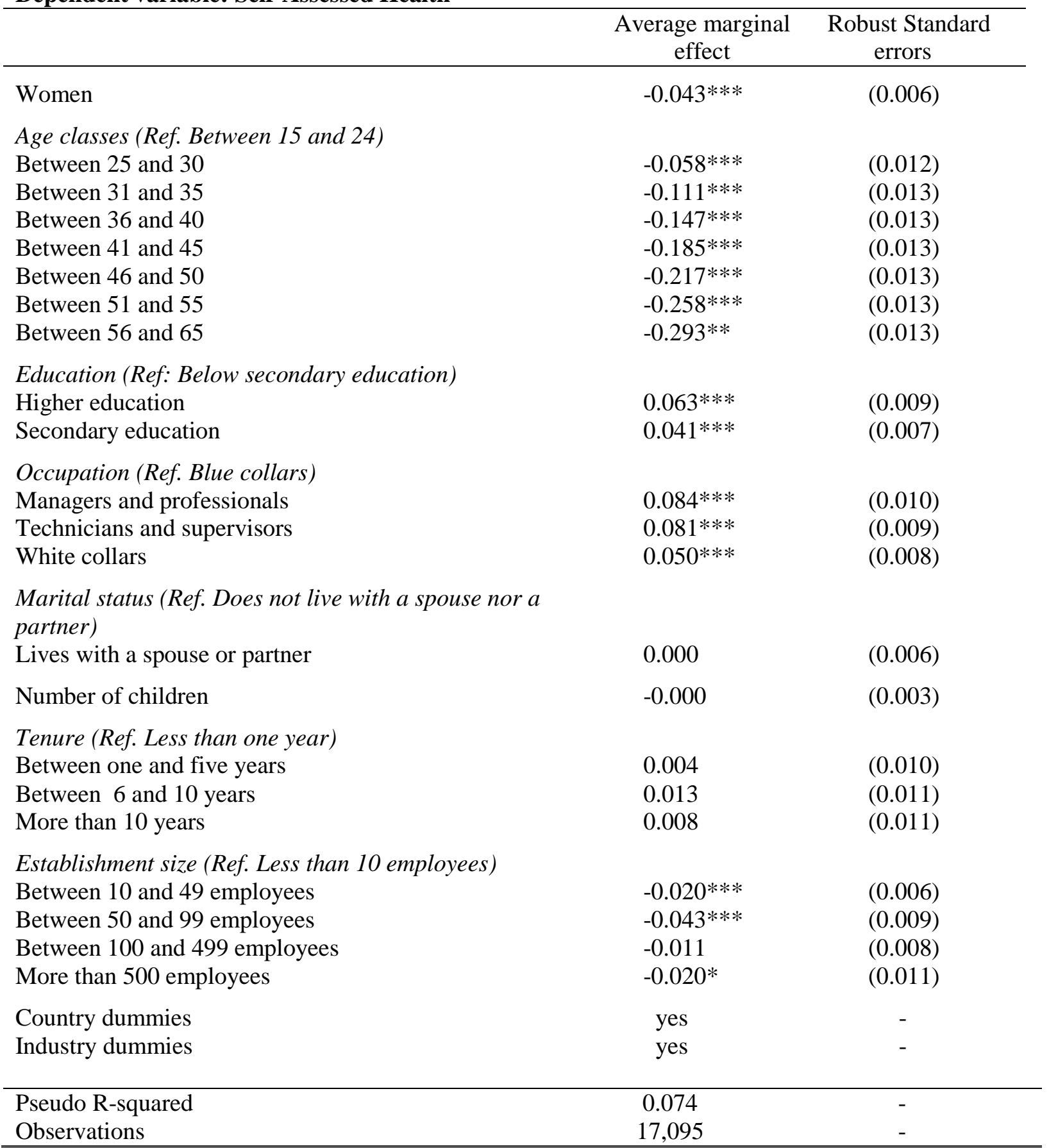


Appendix Tables (not for publication)

Table A.5: Descriptive statistics - Countries, frequency (\%)

\begin{tabular}{lccc}
\hline Variables & Whole sample & Women & Men \\
\hline \hline & & & \\
Austria & 2.62 & 2.79 & 2.44 \\
Belgium & 10.12 & 9.20 & 11.13 \\
Bulgaria & 2.56 & 2.77 & 2.32 \\
Cyprus & 2.51 & 2.34 & 2.70 \\
Croatia & 2.80 & 2.72 & 2.89 \\
Czech Republic & 2.28 & 2.77 & 2.04 \\
Denmark & 3.07 & 3.00 & 3.15 \\
Estonia & 2.59 & 3.27 & 1.83 \\
Finland & 2.88 & 3.23 & 2.49 \\
France & 8.17 & 8.84 & 7.43 \\
Germany & 5.95 & 5.50 & 6.44 \\
Greece & 2.07 & 1.77 & 2.41 \\
Hungary & 2.62 & 2.74 & 2.50 \\
Ireland & 2.60 & 2.61 & 2.59 \\
Italy & 3.38 & 3.46 & 3.29 \\
Latvia & 2.76 & 3.53 & 1.90 \\
Lithuania & 2.50 & 3.03 & 1.91 \\
Luxembourg & 2.62 & 2.29 & 2.98 \\
Malta & 2.71 & 2.10 & 3.38 \\
Netherlands & 2.60 & 2.48 & 2.73 \\
Norway & 2.98 & 3.08 & 2.88 \\
Poland & 3.28 & 3.48 & 3.06 \\
Portugal & 2.45 & 2.51 & 2.38 \\
Romania & 2.22 & 2.08 & 2.37 \\
Slovenia & 3.70 & 3.97 & 3.42 \\
Slovakia & 2.47 & 2.60 & 2.34 \\
Spain & 2.69 & 2.60 & 2.79 \\
Sweden & 2.68 & 2.93 & 2.40 \\
Turkey & 4.10 & 2.23 & 6.17 \\
United Kingdom & 4.02 & 4.34 & 3.68 \\
\hline Observations & 30124 & 15787 & 14337 \\
\hline & & & \\
\hline
\end{tabular}


Table A.6 - Descriptive statistics: Industries, frequency (\%)

\begin{tabular}{|c|c|c|c|}
\hline Variables & Whole sample & Women & Men \\
\hline Food and beverages & 2.70 & 2.45 & 2.98 \\
\hline Textiles, wearing app. & 1.74 & 2.35 & 1.07 \\
\hline Leather & 0.34 & 0.39 & 0.29 \\
\hline Wood and wood products & 0.70 & 0.38 & 1.05 \\
\hline Paper, printing and publishing & 1.22 & 0.96 & 1.51 \\
\hline Refined petroleum and nuclear fuel & 0.07 & 0.06 & 0.09 \\
\hline Chemicals and chemical products & 0.92 & 0.65 & 1.22 \\
\hline Rubber and plastics & 0.68 & 0.37 & 1.03 \\
\hline Non-metallic mineral products & 0.56 & 0.31 & 0.84 \\
\hline Basic metals and fabricated metal & 2.05 & 0.88 & 3.34 \\
\hline Machinery & 1.13 & 0.52 & 1.79 \\
\hline Electrical and optical equipment & 1.30 & 1.17 & 1.44 \\
\hline Transport equipment & 1.20 & 2.16 & 1.88 \\
\hline Manufacturing, recycling & 1.18 & 0.67 & 1.74 \\
\hline Electricity, gas and water supply & 2.06 & 1.09 & 3.14 \\
\hline Construction & 6.70 & 1.49 & 12.44 \\
\hline Motor trade and repair & 2.15 & 0.77 & 3.67 \\
\hline Wholesale trade & 2.64 & 2.05 & 3.29 \\
\hline Retail trade & 10.97 & 13.99 & 7.64 \\
\hline Hotels and restaurants & 4.79 & 5.40 & 4.12 \\
\hline Transport and storage & 4.89 & 2.16 & 7.90 \\
\hline Post and telecommunications & 1.77 & 1.30 & 2.27 \\
\hline Financial intermediation & 3.32 & 3.54 & 3.07 \\
\hline Real estate activities & 0.80 & 0.85 & 0.74 \\
\hline Renting and business activities & 1.28 & 0.58 & 2.04 \\
\hline Research and development & 5.93 & 6.27 & 5.55 \\
\hline Public administration and defense & 8.15 & 7.23 & 9.15 \\
\hline Education & 10.38 & 14.70 & 5.62 \\
\hline Health and social work & 11.69 & 18.25 & 4.48 \\
\hline Social and personal services & 5.57 & 6.83 & 4.18 \\
\hline $\begin{array}{l}\text { Private households with employed } \\
\text { persons }\end{array}$ & 0.95 & 1.64 & 0.18 \\
\hline $\begin{array}{l}\text { Extra-territorial organization and } \\
\text { bodies }\end{array}$ & 0.20 & 0.14 & 0.26 \\
\hline Observations & 30124 & 1015787 & 14337 \\
\hline
\end{tabular}




\section{Data Appendix (not for publication) Job quality variables}

Painful physical working conditions: this is the normalised sum of 13 indicators. For each of them, respondents are asked whether they are exposed to this type of working condition. Answers range from 1 (Never) to 7 (All of the time).

- Vibrations from hand tools, machinery, tec.

- Noise so loud that you would have to raise your voice to talk to people

- High temperatures which make you perspire even when not working

- Low temperatures whether indoors or outdoors

- Breathing in smoke, fumes (such as welding or exhaust fumes), powder or dust (such as wood dust or mineral dust) etc.

- Breathing in vapours such as solvents and thinners

- Handling or being in skin contact with chemical products or substances

- Handling or being in direct contact with materials which can be infectious, such as waste, bodily fluids, laboratory materials, etc

- $\quad$ Tiring or painful positions

- Lifting or moving people

- Carrying or moving heavy loads

- Standing

- Repetitive hand or arm movements

Work pressure: normalised sum of 5 indicators

- Working more than 48 hours a week: binary variable taking value 1 if so and 0 otherwise

- Commuting more than one hour a day: binary variable taking value 1 if so and 0 otherwise

- Does your job involve? Answers range from 1 (Never) to 5 (Always)

$\circ$ not having enough time to get the work done:

$\bigcirc$ working at very high speed

$\circ$ working to tight deadlines

Work harassment: normalised sum of 3 indicators each of which are binary variables taking value 1 if the individual declares she has been subject to this kind of harassment and 0 otherwise.

- Verbal abuse

- Threats and humiliating behaviour

- Bullying

Emotional stress: normalised sum of 3 indicators built out of the following questions: Does your job involve..

- That you hide your feelings: Answers range from 1 (Never) to 5 (Always)

- Tasks that are in conflict with your personal values: Answers range from 1 (Never) to 5 (Always)

- Handling angry clients: Answers range from 1 (Never) to 7 (All of the time)

Job insecurity: Variable built out of the answer to the following question: "How much do you agree or disagree with the following statement describing some aspects of your job: "I might lose my job in the next 6 months". Answers range from 1 (Strongly disagree) to 5 (Strongly agree).

Decision latitude: normalised sum of 5 indicators built out of the answers to the following questions:

- Are you able to change:

0 your order of tasks: binary variable taking value 1 if so and 0 otherwise

- your methods of work: binary variable taking value 1 if so and 0 otherwise 
○ your speed or rate of work: binary variable taking value 1 if so and 0 otherwise

- Select the response which best describes your work situation:

- you can take a break when you wish: answers range from 1 (Never) to 5 (Always)

○ you are able to apply your own ideas in your work: answers range from 1 (Never) to 5 (Always)

Learning opportunities: normalised sum of 4 indicators built out of the answers to the following questions (each answer is coded as a binary variable taking value 1 or 0 ):

- Does your main job involve:

$\bigcirc$ solving unforeseen problems on your own

$\circ$ learning new things

- Over the past 12 months, have you undergone the following types of training?

○ training paid for or provided by your employer

$\circ$ on-the-job training

Task clarity: normalised sum of 3 indicators built out of the answers to the following questions:

- Select the response which best describes your work situation:

o you know what is expected of you at work: answers range from 1 (Never) to 5 (Always)

- In general, your immediate supervisor/manager

$\circ$ provides you with feedback on your work: binary variable taking value 1 if so and 0 otherwise

$\circ$ is good at planning and organising work: binary variable taking value 1 if so and 0 otherwise

Managerial support: normalised sum of 4 indicators built out of the answers to the following questions:

- Select the response which best describes your work situation:

$\circ$ your manager helps and supports you: answers range from 1 (Never) to 5 (Always)

- In general, your immediate supervisor/manager

- respects you as a person: binary variable taking value 1 if so and 0 otherwise

- is good at resolving conflicts: binary variable taking value 1 if so and 0 otherwise

- encourages you to participate in important decisions: binary variable taking value 1 if so and 0 otherwise

Support from colleagues: normalised sum of 3 indicators built out of the answers to the following questions:

- Select the response which best describes your work situation:

$\circ$ your colleagues help and support you: answers range from 1 (Never) to 5 (Always)

- How much do you agree or disagree with the following statements:

- I feel at home in this organisation: answers range from 1 (Strongly disagree) to 5 (Strongly agree)

- I have very good friends at work: answers range from 1 (Strongly disagree) to 5 (Strongly agree)

Earnings: monthly earnings are grouped into 5 groups corresponding to quintiles, with the first quintile being equal to $3,600 €$, the second one to $7,200 €$, the third one to $15,000 €$ and the fourth one to $21,000 €$.

Employability: Variable built out of the answer to the following question: "How much do you agree or disagree with the following statement describing some aspects of your job: If I were to lose or quit my current job, it would be easy for me to find a job of similar salary". Answers range from 1 (Strongly disagree) to 5 (Strongly agree). 
Work-family balance: Variable built out of the answer to the following question: "In general, do your working hours fit in with your family or social commitments outside work very well, well, not very well or not at all well?" Answers range from 0 (Not at all well) to 3 (Very well). 